$12-2011$

\title{
The Effects of Government Intervention on the Market for Corporate Terrorism Insurance
}

Erwann Michel-Kerjan

University of Pennsylvania

Paul A. Raschky

Follow this and additional works at: https://repository.upenn.edu/fnce_papers

Part of the Economics Commons, Finance and Financial Management Commons, and the Insurance Commons

\section{Recommended Citation}

Michel-Kerjan, E., \& Raschky, P. A. (2011). The Effects of Government Intervention on the Market for Corporate Terrorism Insurance. European Journal of Political Economy, 27 (Supplement 1), S122-S132. http://dx.doi.org/10.1016/j.ejpoleco.2011.03.006 


\title{
The Effects of Government Intervention on the Market for Corporate Terrorism Insurance
}

\begin{abstract}
Nine OECD countries presently have national terrorism insurance programs based on some type of public-private risk sharing. While such arrangements have helped provide the necessary insurance capacity in the post-September 11, 2001 era, little is known about the effect of such governmental intervention on terrorism insurance markets. This paper focuses on the United States, where the Terrorism Risk Insurance Act of 2002 (TRIA) provides insurers with no cost federal reinsurance up to an industry-wide loss of $\$ 100$ billion. We present an empirical analysis to compare how insurers' diversification behavior varies between property coverage (no governmental intervention) and terrorism coverage (with government intervention). We find evidence that insurers in the U.S. are much less diversified for terrorism coverage than they are for property lines of coverage. We interpret these findings as tentative evidence for moral hazard caused by the governmental intervention under TRIA.

Research highlights

- We study the effect of TRIA on insurers' diversification behavior for terrorism lines in the United States. - Policy-level demand and supply data for terrorism and property coverage are compiled from a unique database of hundreds of commercial firms. - Government intervention indeed reduces insurer's portfolio diversification. Government intervention also reduces effect of liquidity concerns in supply decision.
\end{abstract}

\section{Keywords}

terrorism, economics of national security, government intervention, commercial insurance markets

\section{Disciplines}

Economics | Finance and Financial Management | Insurance 


\section{The Effects of Government Intervention on the Market for Corporate Terrorism Insurance}

Article in European Journal of Political Economy · April 2011

DOI: 10.1016/j.ejpoleco.2011.03.006

CITATIONS

6

2 authors:

\section{Erwann Michel-Kerjan \\ University of Pennsylvania}

121 PUBLICATIONS 1,493 CITATIONS

SEE PROFILE
READS

68

Some of the authors of this publication are also working on these related projects: 


\section{The Effects of Government Intervention on The Market for Corporate Terrorism Insurance}

Erwann Michel-Kerjan

Wharton Center for Risk Management, University of Pennsylvania
Paul Raschky

Department of Economics, Monash University, Australia

March 2011

Working Paper \# 2011-05

Risk Management and Decision Processes Center

The Wharton School, University of Pennsylvania

3730 Walnut Street, Jon Huntsman Hall, Suite 500

Philadelphia, PA, 19104

USA

Phone: 215-898-4589

Fax: 215-573-2130

http://opim.wharton.upenn.edu/risk/ 


\section{THE WHARTON RISK MANAGEMENT AND DECISION PROCESSES CENTER}

Established in 1984, the Wharton Risk Management and Decision Processes Center develops and promotes effective corporate and public policies for low-probability events with potentially catastrophic consequences through the integration of risk assessment, and risk perception with risk management strategies. Natural disasters, technological hazards, and national and international security issues (e.g., terrorism risk insurance markets, protection of critical infrastructure, global security) are among the extreme events that are the focus of the Center's research.

The Risk Center's neutrality allows it to undertake large-scale projects in conjunction with other researchers and organizations in the public and private sectors. Building on the disciplines of economics, decision sciences, finance, insurance, marketing and psychology, the Center supports and undertakes field and experimental studies of risk and uncertainty to better understand how individuals and organizations make choices under conditions of risk and uncertainty. Risk Center research also investigates the effectiveness of strategies such as risk communication, information sharing, incentive systems, insurance, regulation and public-private collaborations at a national and international scale. From these findings, the Wharton Risk Center's research team - over 50 faculty, fellows and doctoral students - is able to design new approaches to enable individuals and organizations to make better decisions regarding risk under various regulatory and market conditions.

The Center is also concerned with training leading decision makers. It actively engages multiple viewpoints, including top-level representatives from industry, government, international organizations, interest groups and academics through its research and policy publications, and through sponsored seminars, roundtables and forums.

More information is available at http://opim.wharton.upenn.edu/risk. 


\title{
The Effects of Government Intervention on The Market for Corporate Terrorism Insurance
}

\author{
Erwann Michel-Kerjan ${ }^{\star}, \mathrm{a,b}$, Paul Raschky ${ }^{\mathrm{c}}$ \\ ${ }^{a}$ Center for Risk Management, OPIM Dept., The Wharton School, University of Pennsylvania, \\ Philadelphia, PA, 19104, USA \\ ${ }^{b}$ Department of Economics, Ecole Polytechnique, France \\ ${ }^{c}$ Department of Economics, Victoria, 3800, Monash University, Australia
}

\begin{abstract}
Today, nine OECD countries have national terrorism insurance programs based on some type of public-private risk sharing. While such arrangements helped provide the necessary insurance capacity in the post-September 11, 2001 era, little is known about the impact of such governmental intervention in terrorism insurance markets. This paper focuses on the United States, where the Terrorism Risk Insurance Act of 2002 (TRIA) provides insurers with no cost federal reinsurance up to an industry-wide loss of \$100 billion. We propose an empirical analysis to compare how insurers' diversification behavior varies between property coverage (no governmental intervention) and terrorism coverage (with government intervention). We find evidence that insurers in the U.S. are much less diversified for terrorism coverage than they are for property lines of coverage. We interpret these findings as tentative evidence for moral hazard caused by the governmental intervention under TRIA.
\end{abstract}

JEL classification: D21 (Firm Behavior); G22 (Insurance; Insurance Companies); H56 (National Security and War)

Keywords: terrorism; economics of national security; government intervention; commercial insurance markets.

\footnotetext{
* Correspondence (Michel-Kerjan): erwannmk@wharton.upenn.edu; voice; +1 215573 0515; fax: +1 215573 2130; Raschky:paul.raschky@monash.edu
} 


\section{Introduction}

In the aftermath of the terrorist attacks of the early 1990s in the United Kingdom, and of February 1993 and September 11, 2001 (9/11) in New York City, ${ }^{i}$ we have witnessed a large increase in economic research on the topic of terrorism. This growing literature can be subdivided into several major strands. ${ }^{\text {ii }}$ The first one investigates the causes and origins of terrorism, the formation of terrorist movements, their behavior (Hoffman, 1998; Stern, 2003; Sandler and Enders, 2004), and whether and, if so, how related is the engagement in terrorist activities to economic factors such as poverty or education (e.g., Krueger and Maleckova, 2003; Blomberg et al., 2004; Enders and Sandler, 2006; Mirza and Verdier, 2008). A second strand of literature examines the effectiveness of counter-terrorism activities and how counter-terrorist policies may be improved (e.g., Lapan and Sandler, 1988; Lee, 1988; Frey and Luechinger, 2004; Sandler and Enders, 2004; Brück, 2007).

The third area of research deals with the consequences of terrorism on society. For instance, several empirical studies in economics have been conducted on the effects of terrorism on a variety of indicators such as GDP (Tavares, 2004), life satisfaction and happiness (e.g., Frey et al., 2009), companies' stock value (Abadie and Gardeazabal, 2003; Doherty et al., 2003; Brown et al., 2004; Berrebi and Klor, 2010), foreign direct investment (Enders et al., 2006), vacancy rate in business offices of large cities (Abadie and Dermisi, 2008) and tourism activities (Drakos and Kutan, 2003).

Ensuring the economic resiliency of the victims of terrorist attacks (people and firms) constitutes an important pillar in limiting the consequences of such attacks. Here we center on the role that insurance can play in that process. While the countries of France, Israel, Spain, South Africa and United Kingdom have a long history of terrorism on their soil and, as a result, had already developed national solutions to provide compensation to victims of terrorist acts, the attacks of September 11, 2001 revealed a totally new dimension of exposure to insurers, reinsurers and governments around the world. The events cost the insurance industry over $\$ 32$ billion (in 2001 prices), iii that is one of the most costly disasters in the history of insurance worldwide, second only to Hurricane Katrina in $2005^{\mathrm{iv}}$.

In the aftermath of these attacks, reinsurers around the world decided to stop covering this risk, leaving primary insurers operating in the United States with no possibility of transferring the risk to much more diversified entities. As a result, insurers refused to cover terrorism without some type of governmental backstop (OECD, 2005). Then, we witnessed the emergence of a number of governmental policies to counteract this market failure.

This paper focuses on the effects of such governmental intervention into terrorism insurance markets. After 9/11 the United States passed the Terrorism Risk Insurance Act of 2002 (TRIA) that established a specific terrorism risk-sharing arrangement between private insurers and the federal government, the latter providing no upfront cost reinsurance up to a total insured loss in the country of $\$ 100$ billion. Because such an arrangement does not exist for other catastrophic risks such as floods or hurricanes, the post-9/11 U.S. corporate terrorism insurance market is an ideal 
subject for undertaking an empirical comparison between markets with and without governmental intervention.

The paper is organized as follows. Section 2 discusses how terrorism is covered in several OECD countries, including Israel, Spain, the United Kingdom, France and Germany (chronologically ordered by the date of the creation of their national terrorism loss coverage programs). Section 3 discusses more specifically the U.S. market for terrorism insurance before and after September 2001, and how government intervention has modified it with the passage of TRIA. Section 4 introduces the data, discusses the methodology and analyzes the results. We use a unique cross-section sample of hundreds of large U.S. corporations' insurance policies on property and terrorism risk provided to us by Marsh, one of the largest insurance brokers in the world. This demand side information is combined with features from the respective primary insurer to construct a policy-level dataset for two lines of coverage: property and terrorism. We estimate the effects of the primary insurers' diversification and risk management features on the amount of coverage offered for each type of risk. We find that primary insurers take into account the marginal effect of client concentration on their portfolio's diversification in the case of property but not for terrorism risk. In addition, we find that considerations about the primary insurer's ability to adjust for a large loss play a role for property insurance but not for terrorism. A robustness test using data on commercial flood and wind coverage (potentially catastrophic as well but with no government intervention in the insurance lines we study here) reveals that our results are not driven by the catastrophic nature of terrorism risk. Our findings are robust to the application of different estimators as well as the exclusion of clients from specific industries, client companies by type and size, as well as insurers. These findings indicate that in the market for commercial terrorism insurance, primary insurers are less concerned about the costs of bearing the risk from a major loss. We interpret these results as tentative evidence for moral hazard caused by the governmental back-up under TRIA. Although our results should be interpreted carefully due to the limitations of a cross-sectional analysis in this context, we are confident that our analysis provides some explorative and new insights on the effect of governmental intervention in the market for corporate insurance. Section 5 concludes.

\section{Terrorism, government and insurance}

Catastrophic events present special challenges for economics and risk management since they have an immediate impact on a wide range of stakeholders, can have severe long-term economic and social consequences and are difficult to assess quantitatively. As these events have a low probability of occurrence, there are limited historical data on which to base estimates of the risks, and there is considerable uncertainty associated with experts' risk assessment estimates. Aversion to ambiguity leads insurers to set premiums much higher than they would if there was agreement among experts as to the likelihood and consequences of future events (Kunreuther et al., 1993; Cabantous et al., forthcoming). Facing unprecedented potential large-scale damage which would require insurers to hold a very large amount of capital (or otherwise face bankruptcy; Cummins 
et al., 2002), the private insurance sector may severely restrict the insurance supply or even refuse to provide such coverage.

But because these events are capable of having a debilitating impact on the country, providing adequate financial protection to victims of catastrophes often becomes a national issue. In such cases, the government is likely to intervene by offering insurance at prices that enterprises can afford and to address equity issues (Moss, 2002). On the demand side, it is well known that individuals, as potential purchasers of catastrophe insurance, may underestimate the risks and consider the insurance premiums to be too expensive, thus refusing to purchase coverage if they have the choice (Kunreuther and Michel-Kerjan, 2009).

Terrorism risk insurance shares these characteristics. ${ }^{\vee}$ Before we discuss the U.S. terrorism insurance market in more detail in the next section, it is interesting to observe what role governments in other countries have played in providing financial coverage against losses from terrorist attacks (U.S. Government Accountability Office, 2005; OECD, 2005).

Israel: In this country with a long history of terrorist attacks, losses from attacks are compensated directly by the state according to a pre-defined formula. Any direct and indirect damage occurring within Israel due to war or hostilities will be covered by a public compensation fund built from the general property tax collected across the country, according to regulations. Insurers do not cover this risk.

Spain: Terrorism has been covered as part of the state-backed insurance compensation scheme for "extraordinary risks" (including also storms, floods, earthquakes, riots), by the 1954-established Consortio de Compensation de Seguros. Coverage for these risks is included as an add-on to property insurance sold by private insurers which sell the policy but are not financially responsible for losses from such extraordinary risks. ${ }^{\mathrm{vi}}$ The private sector has never expressed an interest in covering these catastrophic risks. In the aftermath of the March 11, 2004 terrorist attacks in Madrid, the Consortio paid 41 million euros in claims (railway vehicles were not insured). The December 2006 attacks against the Barajas Airport triggered another 46 million euros in claims. These claims were rapidly paid by the Spanish catastrophe fund which currently has over 4 billion euros in reserve and has never used the state guarantee in over 50 years of operation.

United Kingdom: In the wake of the series of attacks in the early 1990s, the United Kingdom established a mutual reinsurance organization (Pool Re) in 1993 for commercial property and business interruption to cover claims only from acts of terrorism. Pool Re acts as a reinsurer for all insurers that wish to be a member of the pool. The U.K. Treasury provides Pool Re with unlimited debt issuance. Pool Re pays 10 percent of its collected premiums to the British government in return for this coverage.

France: GAREAT was launched on January 1, 2002. It is a co-reinsurance pool which includes all insurance companies licensed to operate in France. The risk sharing under GAREAT is organized under several layers. The first series of layers are covered by French and international insurers and reinsurers; the top layer is an unlimited guarantee above 2 billion euros provided by the French government via the Caisse Centrale de Réassurance, a state-owned reinsurance company. The government receives about 10 
percent of the total annual terrorism premiums collected by primary insurers in exchange for this backstop (Michel-Kerjan and Pedell, 2005; 2006).

Germany: Extremus AG was created in November 2002. It is a private insurance company dedicated to covering terrorism risks and composed of 15 insurers and reinsurers domiciled in Germany. As is the case in France, Extremus also benefits from property reinsurance from the federal government. The government provides 8 billion euros of reinsurance in excess of 2 billion covered by the private market. In exchange, the government receives about 12.5 percent of the premiums collected by Extremus. vii

\section{The U.S. market for terrorism risk insurance}

\subsection{Terror insurance markets before and immediately after 9/11}

Before 9/11, major insurance losses from terrorism were viewed as so improbable that the risk was not explicitly mentioned in standard policy (outside of transportation insurance) and hence the rate for providing such coverage to firms was never calculated. Terrorism was covered de facto in most commercial insurance contracts (Kunreuther and Michel-Kerjan, 2004). One of the first attacks to significantly impact the insurance industry occurred in the U.K. in 1992 and cost insurers nearly $\$ 700$ million (indexed to 2001) (Swiss Re, 2002). Then in 1993, three other major terrorist attacks occurred. The first was the bombing of the World Trade Center in New York City in February 1993, perpetrated in one of the garages of the Towers. The bombing killed six people and injured one thousand, and caused $\$ 725$ million in insured damages. The second was a series of 13 bomb attacks in India that killed 300 and injured 1,100 others. Given the lack of insurance coverage there, these attacks had no major impact on insurers, though. The third major attack occurred with a bomb exploding near NatWest tower in April 1993 in London. This attack triggered \$900 million in insured losses.

Notably, the British insurers recognized the significance of these earlier attacks for the future of their industry. In response, as discussed above, they created a dedicated terrorism insurance program that same year, Pool Re. Surprisingly, insurers in the United States - and those international insurers and reinsurers covering activities in the U.S. - continued to cover this peril without explicitly pricing it in their commercial insurance policies. Two years later, the Oklahoma City bombing killed 168 people, but the largest losses were to federal property and employees, and were covered by the government. In 1998, bomb attacks on the U.S. embassy complex in Nairobi, Kenya killed more than 250 people and injured 5,000 others. Still, U.S. insurers and international reinsurers operating there continued to cover terrorism as they had done before. As Berkshire Chairman Warren Buffett said in his 2001 letter to shareholders, "we, and the rest of the industry, included coverage for terrorist acts in policies covering other risks, and received no additional premium for doing so."

Things radically changed on September 11, 2001. The Al Qaeda attacks killed more than 3,000 people ${ }^{\text {viii }}$ from over 90 countries and injured more than 2,250 others. The attacks also inflicted damage estimated at nearly $\$ 80$ billion, about $\$ 32.5$ billion (2001 prices) of which was covered by nearly 150 insurers and reinsurers worldwide 
(including \$21 billion for damage and business interruption alone) (U.S. Treasury et al., 2006). Private reinsurers, who covered a majority of these losses, then decided to exit this market, leaving insurers without protection. A few months after 9/11, insurers had excluded terrorism from their policies in most states. Commercial enterprises thus found themselves in a very difficult situation, with insurance capacity extremely limited and priced very high.

Consider the case of insuring Chicago's O'Hare Airport. Prior to 9/11, the airport had $\$ 750$ million of terrorist insurance coverage at an annual premium of $\$ 125,000$. After the terrorist attacks, insurers offered the airport only $\$ 150$ million of coverage at an annual premium of $\$ 6.9$ million (a 200-fold cost difference since the 9/11 attacks). The airport purchased this coverage and could not obtain any more capacity (Jaffee and Russell, 2005). Another example is the Golden Gate Park in San Francisco, which was unable to obtain terrorism coverage; moreover, even its non-terrorism coverage was reduced from $\$ 125$ million to $\$ 25$ million-and the premiums for this reduced amount of protection increased from $\$ 500,000$ in 2001 to $\$ 1.1$ million in 2002 (Smetters, 2004). One year after $9 / 11$, when national security had become the "number one" priority on the agenda of the United States and internationally, the country's commercial enterprises remained largely uninsured at home (Hale, 2002). If another large-scale attack had occurred at that time, the impact on the local economy could have been much more serious than it was on 9/11. The economic losses would not have been spread over a large number of insurers and reinsurers worldwide but, in the absence of massive post disaster federal relief, sustained by the firms themselves.

\subsection{Terrorism insurance under the current public-private TRIA arrangement}

The lack of availability of terrorism insurance shortly after the 9/11 attacks led to a call from some private sector groups for federal intervention. For example, the U.S. Government Accountability Office reported in 2002 that the construction and real estate industries claimed that the lack of available terrorism coverage delayed or prevented several projects from going forward because of concerns by lenders or investors (U.S. GAO, 2002).

In response to such concerns, the Terrorism Risk Insurance Act of 2002 (TRIA) was passed by Congress and signed into law by President Bush on November 26, $2002 .^{i x}$ This program was originally aimed at providing a three-year temporary measure to increase the availability of risk coverage (U.S. Congress, 2002), but the program has been renewed twice since. TRIA is now extended up to the end of 2014, and could be extended again in the future. ${ }^{x}$

TRIA operation is somewhat complex and it is not the purpose of this paper to analyze it in detail. Still, there are features of TRIA that will be important for this analysis and also for potential policy implications of our results. TRIA requires insurers to offer terrorism coverage to all their commercial clients (a legal "make available" requirement). (Note that residential coverage is not included in this program). These firms have the right to refuse this coverage unless it is mandated by state law, as in the case of workers' compensation lines in most states. ${ }^{\mathrm{xi}}$ Loss sharing under TRIA is organized as follows: The first layer is provided by insurers through a deductible they must assume. 
The deductible is calculated as a percentage of the direct commercial property and casualty earned premiums of each insurer in the preceding year. This percentage has increased sharply over time: 7 percent in 2003, 10 percent in 2004, 15 percent in 2005, and it has been 20 percent since 2007. The second layer up to $\$ 100$ billion is the joint responsibility of the federal government and insurers. Specifically, the federal government is responsible for paying 85 percent $^{\text {xii }}$ of each insurer's primary losses during a given year above the applicable insurer deductible; the insurer covers the remaining 15 percent.

Another notable feature of TRIA is that, contrary to what is done in France, Germany and the U.K., the U.S. federal government does not collect any premium for

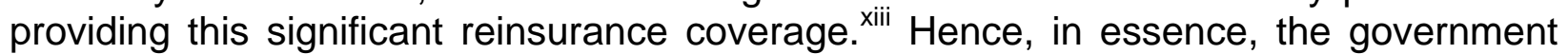
intervened to provide insurers with free reinsurance for exposure which would ordinarily require a substantial amount of (costly) capital should the insurers seek capacity from the private reinsurance market.

The policy goal here was to ensure that commercial firms across the nation could access highly subsidized coverage, and as a result more companies should purchase this coverage. Indeed, in the absence of a large insurance market, the federal government would be likely to intervene in the aftermath of another large-scale attack to provide relief to the uninsured victims of the attack. The expectation of ex-post financing of losses by the government would reduce firms' willingness to pay premiums at a level insurers would like to charge (Smetters, 2004). ${ }^{\text {xiv }}$ This can lead to moral hazard in that firms would purchase less insurance coverage and invest less in physical risk reduction measures.

Evidence shows that the subsidized insurance cost strategy of TRIA has worked. Market data from Marsh, one of the world larger insurance brokers, indicate that commercial take-up rates for terrorism insurance in the U.S. have more than doubled from 27 percent in 2003 to 60 percent in 2006, a level that has remained stable since; the take-up rate was 61 percent in 2009 (Marsh 2010). This is partly due to the fact that terrorism insurance prices have continuously decreased since 2003. ${ }^{\mathrm{XV}}$

It is not clear, however, how this federal intervention has impacted insurers' behavior on the supply side. This is an important issue if TRIA is to become a permanent program. If so, the government intervention will likely become permanent, too. As such, it can permanently distort the market by displacing long term private market activity that could have otherwise emerged (Jaffee and Russell, 2005; Jaffee, 2005). Specifically, our empirical analysis in the next section focuses on the following question: Are insurers taking on more terrorism risks than they would otherwise, knowing that they collect all the terrorism insurance premiums under TRIA but are responsible for only a portion of the loss? 


\section{Empirical analysis}

\subsection{Focus and hypotheses}

In order to identify the effect of government intervention in the U.S. market for commercial terrorism insurance, we use contract-level data from primary insurers. We observe, for several lines of coverage, the insurance policies that each insurer offered to its clients (see description of the data in the next subsection). We include only insurer-client dyads in our sample that have both terrorism insurance and property insurance. Therefore, we eliminate a potential bias that could emerge if some form of coverage were offered only by a certain type of insurer and/or demanded by a certain type of commercial client in our sample. This dataset allows us to compare how the insurers' supply of an additional unit of coverage differs between terrorism insurance (with government intervention) and property insurance (without government intervention). We also perform a robustness check using information on commercial wind and flood policies (catastrophic, without intervention from the federal government. ${ }^{\text {xvi }}$ )

Our empirical analysis is based on Kleffner and Doherty (1996) who identify a number of factors that determine insurers' ability to write corporate coverage. It mainly depends on the characteristics of their portfolio of corporate clients and on financial indicators that have an impact on the cost of risk-bearing.

For each insurer in our sample, we measure the risk exposure the insurer faces by determining its maximum exposure in its entire portfolio (maximum compensation on each one of its contracts). The decision to provide an additional unit of coverage against a given risk in a certain location depends on the insurer's ability to bear the costs associated with it (i.e., possible claim).

One important determinant, then, is what portion of the insurer's entire portfolio one given commercial client represents. In general, insurance companies try to diversify their exposure by spreading it over a number of clients. In the case of homeowners' insurance, the insurers can spread this risk over tens of thousands, if not millions, of customers, each of them representing a very small exposure. The situation is different for commercial insurance, since corporations have large exposure and concentration of assets. Moreover, the number of large commercial clients in an insurer's portfolio is typically much lower. Still, to conserve a certain degree of diversification, the insurer would not want its portfolio to be dominated by one or two companies: any catastrophic event affecting such clients could seriously impact its financial balance, if not lead to bankruptcy. Hence, the larger the share of a single commercial contract in the insurer's portfolio, the less likely its willingness to offer an additional unit of coverage, because this would only further increase the concentration of exposure to one single customer and decrease the degree of diversification. We expect the size of the coefficient to be smaller (or insignificant) in the case of terrorism due to the federal reinsurance under TRIA.

A second and somewhat related indicator for the insurer's ability to spread risk is geographical diversification. Catastrophic events such as a terrorist attack, flooding, or hurricane might affect an entire region and trigger large claim payments if many clients 
are located in the same geographical area. This would less of a concern for property coverage, since risks are more likely to be independent from one client to the other in the same location. Therefore, the willingness to offer additional catastrophe risk coverage decreases with the increased number of clients whose operations are already located in the same region. This effect should be more pronounced for these catastrophe lines than it would be for property insurance.

Another factor driving the insurer's willingness to write large exposures of risk is its financial ability to absorb major loss shocks. In line with Kleffner and Doherty (1996) we use the insurer's leverage (defined as the ratio of liabilities/assets) as an empirical proxy for its ability to deal with financial distress. We expect that the lower an insurer's leverage, the higher its ability to absorb large claim amounts will be, and therefore the higher the degree of coverage it can offer.

There are a number of other factors that can have an influence on the degree of coverage. We add the insurer's credit rating as a control variable. A better credit rating decreases the costs for reinsurance and also decreases the costs of short-term lending in the case of a catastrophic event that triggers a large amount of claims. In addition, we control for the location of the client's headquarters and industry type with region and industry specific fixed effects.

\subsection{Data}

We compiled data from two sources. The insurance policy sample was provided by Marsh. It contains commercial policy data for terrorism, property, flood and wind insurance contracts they brokered to all their commercial clients in 2007. These are typically large firms, with assets ranging from a few million dollars to over $\$ 70$ billion. Client identities were kept anonymous through the use of random ID numbers designed specifically for this study. Data was reported through an internal internet form completed by brokers of the different Marsh offices in the U.S. We assumed that any broker or office idiosyncrasies were randomly distributed across the dataset. Each individual contract mainly covers multiple locations for a single company, $j$. For each type of insurance, $i$, we constructed our dependent variable, cover.

Cover represents the degree of coverage and is defined as the ratio between the total limit of the insurance policy over the client's total insured value (TIV). This variable is calculated for each type of risk. For instance, if cover for property insurance for a corporate client in a given insurer's portfolio is 20 percent, this means that the maximum compensation (hence insurer's liability) the client can obtain represents 20 percent of all its insured assets with that insurer. In addition, we use the log value of the insurance policy limit, In (policy limit), as an explanatory variable to account for contract size effects (e.g., discounts for larger contracts due to economies of scale). The Marsh dataset also includes information of the client's industry and the location of its headquarters. Both the risk and the insurer's ability to diversify its portfolio might be influenced by these factors. We therefore include region and industry dummies as additional control variables.

Data on the primary insurance company stems from the insurance rating agency AM Best. The contracts in our sample are supplied by twenty-six large insurance 
companies operating in the U.S. Our empirical proxy for each contract's share in the insurers' portfolio (noted "s" for supply), limit/premiums coll, is the ratio of the insurance policy limit of risk type $i$ (property, terrorism, flood or wind), purchased by corporate client company $j$ from insurer $s$ and the limit insurer $s$ ' total premiums collected in the year 2007. For terrorism insurance, these are the premiums collected in the TRIA lines, while for property, flood and wind these are the total premiums collected. Because most of our analysis focused on the comparison between terrorism and property, Figure 1, panel a) plots the limit/premiums coll against the degree of coverage for each terrorism policy, while panel b) plots the limit/premiums coll against the degree of coverage for each property policy. In the case of terrorism we can see a positive relationship between limit/premiums coll and degree of coverage, while for the property risk the contract's share in the insurer's portfolio depicts a negative relationship.

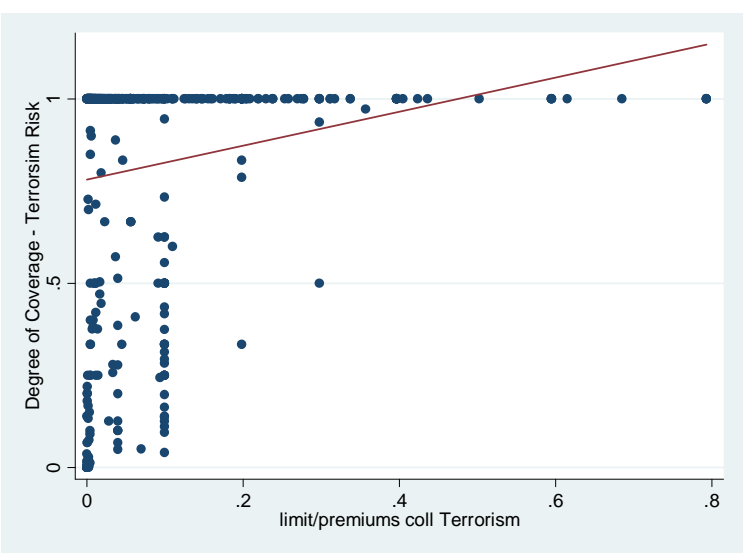

a) Terrorism risk

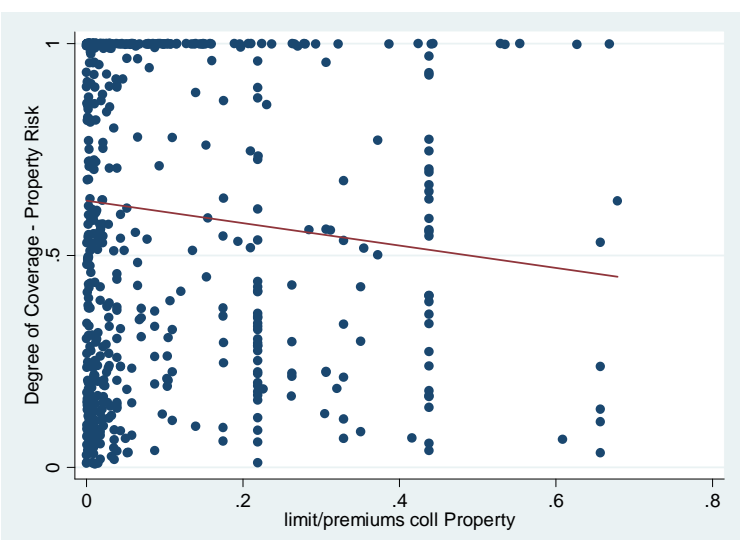

b) Property risk

Fig 1. Diversification and degree of coverage

As discussed, another factor influencing the cost of risk bearing is the insurer's leverage, noted leverage here, which is defined as the ratio of insurer $s$ ' liabilities over its assets. We further use the log value of the insurer $s^{\prime}$ assets, In(assets), to account for size. We also include dummy variables of AM Best's credit rating as a proxy for insurer $s$ ' financial strength. Table 1 provides the descriptive statistics for each type of line of coverage. 
Table 1. Descriptive Statistics

\begin{tabular}{|c|c|c|c|c|c|}
\hline Variable & Obs & Mean & Std. Dev. & Min. & Max. \\
\hline \multicolumn{6}{|c|}{ Terror } \\
\hline cover $_{i j s}$ & 549 & 0.825 & 0.327 & 1.0E-05 & 1.000 \\
\hline limit $_{i j s} /$ premiums coll. ${ }_{\text {js }}$ & 549 & 0.076 & 0.124 & 7.4E-08 & 0.79 \\
\hline In(policy limit $\left.t_{i j s}\right)$ & 549 & 18.542 & 1.712 & 7.379 & 21.416 \\
\hline $\ln \left(\right.$ assets $\left._{s}\right)$ & 549 & 17.112 & 1.082 & 13.557 & 18.641 \\
\hline leverage $_{s}$ & 549 & 0.653 & 0.114 & 0.508 & 0.810 \\
\hline \multicolumn{6}{|c|}{ Property } \\
\hline cover $_{i j s}$ & 654 & 0.607 & 0.373 & 0.008 & 1.000 \\
\hline limit $_{i j s} /$ premiums coll. $_{. j s}$ & 654 & 0.086 & 0.138 & $5 \mathrm{E}-06$ & 0.679 \\
\hline In(policy limit $\left.t_{i j s}\right)$ & 654 & 18.839 & 1.331 & 13.377 & 21.162 \\
\hline $\ln \left(\right.$ assets $\left._{s}\right)$ & 654 & 17.209 & 1.152 & 11.406 & 18.641 \\
\hline leverage $_{s}$ & 654 & 0.664 & 0.108 & 0.508 & 0.810 \\
\hline \multicolumn{6}{|c|}{ Flood } \\
\hline cover $_{i j s}$ & 895 & 0.154 & 0.205 & $1.8 \mathrm{E}-05$ & 1.000 \\
\hline limit $_{i j s} /$ premiums coll. ${ }_{\text {js }}$ & 895 & 0.064 & 0.349 & 7.35E-06 & 4.352 \\
\hline In (policy limitijs $)$ & 895 & 17.196 & 1.539 & 10.820 & 21.060 \\
\hline $\ln \left(\right.$ assets $\left._{s}\right)$ & 895 & 16.935 & 1.558 & 7.079 & 18.641 \\
\hline leverage $_{s}$ & 895 & 0.652 & 0.118 & 0.164 & 0.810 \\
\hline \multicolumn{6}{|c|}{ Wind } \\
\hline cover $_{i j s}$ & 407 & 0.336 & 0.351 & $9.1 \mathrm{E}-05$ & 1.000 \\
\hline limitijs $_{\text {premiums coll. }}$.js & 407 & 0.276 & 2.257 & 1.33E-07 & 43.518 \\
\hline In(policy limitijs $)$ & 407 & 18.296 & 1.844 & 8.226 & 22.333 \\
\hline $\ln \left(\right.$ assets $\left._{s}\right)$ & 407 & 17.185 & 1.637 & 7.079 & 18.641 \\
\hline leverage $_{s}$ & 407 & 0.676 & 0.124 & 0.164 & 0.810 \\
\hline
\end{tabular}

\subsection{Estimation methodology and results}

The bounded nature of the dependent variable (cover is by definition always between 0 and 1 ) as well as the fact that many of our observations are concentrated at the upper boundary are such that applying a standard OLS regression or an OLS regression with non-linear transformation of the explanatory variable does not guarantee that the predicted results lie within the range of the independent variable's interval (we will thus apply an OLS regression only as a robustness check). Papke and Wooldridge (1996) developed a quasi-maximum likelihood estimator (QMLE hereafter) to obtain robust results in that case. We adopt the same methodology here. 
The functional form is as follows:

$$
E\left(Y_{i j r} \mid X_{i j r}\right)=h\left(X_{i j r} \beta\right)
$$

$Y$ represents the degree of insurance coverage for risk type $i, X$ is a vector of covariates, $h$ is the cumulative distribution function (cdf) and $\beta$ is a $\mathrm{k} \times 1$ vector of the coefficients to be estimated. We adjust the standard errors for within-insurer clusters.

Table 2 presents the marginal effects. The coefficient of limit/premiums collected (0.259 ) is negative and significant for property. This means that a contract with a share higher by10 percentage points in the insurer's portfolio receives on average 2.6 percentage-points less coverage for property. This suggests that insurers are less willing to offer an additional unit of property coverage to a client that already has a high share in the portfolio. In contrast, this variable yields a positive and significant coefficient in the case of terrorism insurance $(+0.726)$. A company with a share higher by 10 percentage points in the insurer's portfolio will be offered on average a degree of terrorism coverage which will be 7 percentage points higher. We interpret these results as a first indicator that primary insurers are much less concerned about the concentration of their portfolio in the case of terrorism insurance due to the intervention of the federal government in this market as a no-cost reinsurer. As a matter of fact, the size of the coefficient reveals that insurers will take much more terrorism risks than they would for property risks we study here. This validates our first hypothesis.

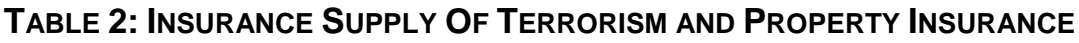

- QUASI-MAXIMUM LIKELIHOOD ESTIMATE

\begin{tabular}{|c|c|c|c|c|}
\hline & Terror & Property & Terror & Property \\
\hline limit $_{i j s} /$ premiums coll.js & $\begin{array}{c}0.726^{\star * \star} \\
(0.145)\end{array}$ & $\begin{array}{c}-0.259^{\star \star *} \\
(0.097)\end{array}$ & $\begin{array}{c}0.619 * \star * \\
(0.095)\end{array}$ & $\begin{array}{l}-0.393^{*} \\
(0.221)\end{array}$ \\
\hline In (policy limit $\left.t_{i j s}\right)$ & & & $\begin{array}{c}0.052^{\star \star *} \\
(0.016)\end{array}$ & $\begin{array}{c}-0.048^{\star * *} \\
(0.015)\end{array}$ \\
\hline $\ln \left(\right.$ assets $\left._{s}\right)$ & & & $\begin{array}{l}0.040^{*} \\
(0.023)\end{array}$ & $\begin{array}{l}-0.003 \\
(0.037)\end{array}$ \\
\hline leverage $_{s}$ & & & $\begin{array}{l}0.387^{*} \\
(0.227)\end{array}$ & $\begin{array}{c}-1.200 * * * \\
(0.295)\end{array}$ \\
\hline AM Best Rating ${ }^{a}$ & No & No & Yes & Yes \\
\hline Industry $F E^{b}$ & No & No & Yes & Yes \\
\hline Region $F E^{c}$ & No & No & Yes & Yes \\
\hline No. of obs. & 549 & 654 & 549 & 654 \\
\hline Log Likelihood & -227.314 & -373.195 & -171.803 & -262.032 \\
\hline
\end{tabular}

Notes: Standard errors (in parenthesis) are adjusted for within-insurers-clustering.

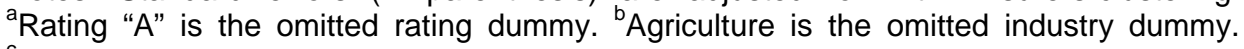
${ }^{\circ}$ Central Midwest is the omitted region dummy. ${ }^{* * *},{ }^{* *},{ }^{*}$ denote significance at the $1 \%$, $5 \%$ and $10 \%$ levels, respectively. 
Another finding is that larger insurance companies are more willing to provide higher degrees of terrorism coverage. However, this coefficient is only significant at the 10 percent level (a coefficient of 0.040 for $\ln \left(\right.$ assets $_{s}$ )in Table 2). Insurer's size does not affect the degree of coverage for property.

Our second variable for risk-management is leverage. Once again, we find that risk management plays a significant role in the case of property (coefficient of -1.200 ) but not in the case of terrorism. A higher value of leverage suggests that the insurer is less able to absorb large financial shocks. Interestingly, the coefficient in the case of terrorism insurance $(0.387)$ is even positive and weakly significant. We again interpret these results as an indication that governmental intervention in the market crowds out incentives for the insurer to consider the risks to liquidity in their supply decision for terrorism coverage.

While, as discussed, the QMLE is the best estimate given the nature of our analysis, we still wanted to verify how sensitive our estimates were to the econometric estimator we used. We reran our main specification including all controls using OLS and Tobit instead of the QMLE. Table 3 shows that our key results are not affected by the choice of the estimator (the sign and significance of our key variables of interest do not change) but of course there are some changes in the size of the coefficients.

TABLE 3: Robustness Test 1 - OLS AND ToBit Estimates

\begin{tabular}{|c|c|c|c|c|}
\hline & \multicolumn{2}{|c|}{ OLS } & \multicolumn{2}{|c|}{ Tobit } \\
\hline & Terror & Property & Terror & Property \\
\hline \multirow[t]{2}{*}{ limit $_{i j s} /$ premiums coll. ${ }_{. j s}$} & $0.323^{\star \star \star}$ & $-0.634^{\star \star}$ & $2.905^{\star \star}$ & $-0.634^{\star \star}$ \\
\hline & $(0.106)$ & $(0.288)$ & $(0.236)$ & $(0.281)$ \\
\hline \multirow{2}{*}{$\ln \left(\right.$ policy limit $\left._{i j s}\right)$} & $0.084^{* * *}$ & -0.014 & $0.145^{\star \star \star}$ & $-0.036^{\star \star \star}$ \\
\hline & (0.019) & $(0.036)$ & $(0.003)$ & $(0.014)$ \\
\hline \multirow[t]{2}{*}{$\ln \left(\right.$ assets $\left._{s}\right)$} & 0.035 & 0.003 & $0.196^{\star \star \star}$ & -0.012 \\
\hline & $(0.030)$ & $(0.037)$ & $(0.003)$ & $(0.035)$ \\
\hline \multirow[t]{2}{*}{ leverage $_{s}$} & 0.553 & $-1.094^{\star \star}$ & $1.267^{\star \star \star}$ & $-1.094^{\star \star \star}$ \\
\hline & $(0.353)$ & $(0.404)$ & $(0.076)$ & $(0.394)$ \\
\hline AM Best Rating ${ }^{a}$ & Yes & Yes & Yes & Yes \\
\hline Industry $F E^{b}$ & Yes & Yes & Yes & Yes \\
\hline Region $F E^{c}$ & Yes & Yes & Yes & Yes \\
\hline No. of obs. & 549 & 654 & 549 & 654 \\
\hline $\mathrm{R}^{2}$ & 0.313 & 0.340 & & \\
\hline Pseudo $\mathrm{R}^{2}$ & & & 0.188 & 0.275 \\
\hline
\end{tabular}

Notes: Standard errors (in parenthesis) are adjusted for within-insurers-clustering.

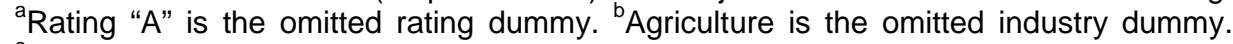
${ }^{\mathrm{C}}$ Central Midwest is the omitted region dummy. ${ }^{* \star *},{ }^{\star *},{ }^{*}$ denote significance at the $1 \%$, $5 \%$ and $10 \%$ levels, respectively. 
So far, we have been comparing terrorism -- a catastrophic risk -- with property risk, a non-catastrophic risk. The differences in the effect of the insurer's portfolio diversification could possibly be driven by the catastrophic nature of the risk and not by the governmental intervention in the market. We therefore use data on insurance supply of other risks associated with potential highly concentrated losses, flood and wind (hurricanes/storms).

The results in Table 4 reveal that the diversification variable depicts a negative effect on the degree of coverage offered both for flood and wind. This suggests that the positive sign we found in our previous analysis (Table 3) in the case of terrorism risk is not necessarily linked to the catastrophic nature of the risk. Most likely it is the result of the possibility for insurers to transfer a large portion of their exposure to terrorism risk to the federal government without having to pay anything for such reinsurance, something they cannot do in the case of flood, wind, or property risk. xvii

TABle 4: Robustness Test 2 - Insurance Supply of Other Catastrophic QUASI-MAXIMUM LIKELIHOOD ESTIMATE

\begin{tabular}{|c|c|c|c|c|}
\hline & Flood & Wind & Flood & Wind \\
\hline limit $_{i j s} /$ premiums coll. $_{. j s}$ & $\begin{array}{l}-0.009 \\
(0.015)\end{array}$ & $\begin{array}{l}-0.003 \\
(0.005)\end{array}$ & $\begin{array}{c}-0.051^{\star \star} \\
(0.021)\end{array}$ & $\begin{array}{c}-0.024^{\star *} \\
(0.011)\end{array}$ \\
\hline In (policy limit $\left.{ }_{i j s}\right)$ & & & $\begin{array}{c}0.027^{\star * *} \\
(0.008)\end{array}$ & $\begin{array}{c}0.062^{\star * *} \\
(0.015)\end{array}$ \\
\hline $\ln ($ assets $)$ & & & $\begin{array}{l}-0.011 \\
(0.007)\end{array}$ & $\begin{array}{c}0.003 \\
(0.019)\end{array}$ \\
\hline leverage $_{s}$ & & & $\begin{array}{l}-0.088 \\
(0.101)\end{array}$ & $\begin{array}{c}-0.419^{* *} \\
(0.207)\end{array}$ \\
\hline AM Best Rating ${ }^{a}$ & No & No & Yes & Yes \\
\hline Industry $F E^{b}$ & No & No & Yes & Yes \\
\hline Region $F E^{c}$ & No & No & Yes & Yes \\
\hline No. of obs. & 895 & 407 & 895 & 407 \\
\hline Log Likelihood & -307.292 & -219.842 & -291.616 & -192.931 \\
\hline
\end{tabular}

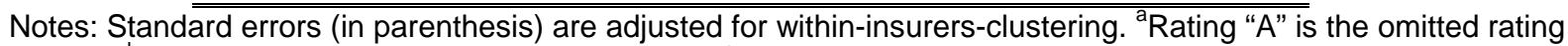
dummy. ${ }^{b}$ Agriculture is the omitted industry dummy. ${ }^{\mathrm{C}}$ Central Midwest is the omitted region dummy. ${ }^{\star \star *},{ }^{\star *},{ }^{*}$ denote significance at the $1 \%, 5 \%$ and $10 \%$ level, respectively.

Although our results reveal an interesting pattern, they need to be put into perspective: this data is only available at cross-section level. Therefore we cannot control for any unobservable differences between terror and the other markets that might drive the differences in the insurers' diversification and risk-management strategies. These omitted variables could probably bias our results. 


\section{Conclusion}

While proper insurance coverage will not prevent the next large-scale terrorist attack, it will provide the necessary financial safety net for corporations and their employees to more quickly recover, providing much needed economic stability. The choice of a specific solution to provide such coverage is one that each country has to make. Culture, insurance market development and exposure to terrorism risks will likely play a key role on what program will be established, if any.

As this paper discussed, despite a series of deadly and costly terrorist attacks around the world in the 1990s, many insurers and governments had not taken action to seriously think about the financial coverage of terrorism risk. The September 11, 2001 attacks obliged these decision makers to rethink the way terrorism losses will be indemnified in the future. Today, nine of the thirty-four OECD countries have set up public-private partnerships, most often with a layered structure approach in which various stakeholders would intervene under pre-determined thresholds and where the government acts as the (re-)insurer of last resort. That is the case of the United States we focused on in this paper. This suggests that a decade after 9/11, the role of government remains critical, not only in trying to prevent future attacks, but also in providing a necessary backstop to stabilize terrorism insurance markets.

The United States implemented the TRIA program, a form of public-private collaboration in which the government provides free upfront reinsurance to insurers. TRIA resulted in many more companies purchasing terrorism coverage. But, as this paper shows empirically, government intervention into this market has had other impacts on insurers' behavior. Specifically, TRIA also resulted in insurers taking on a much higher degree of concentration of their terrorism exposure than they would otherwise do, and certainly more than they do for flood or wind coverage (two other potentially catastrophic risks). This is because insurers are responsible for only a limited portion of their exposure under TRIA; a large proportion of the losses will be transferred to the federal government above each insurer's deductible under this program. As a result, the government assumes much more risks, but does not collect any premium for this.

One open question is whether the U.S. federal government should start charging for this coverage, as is done today in other countries we discussed in this paper. The federal reinsurance cost would certainly be lower than what the private reinsurance market would offer (since the cost of capital would be lower), but still act as an incentive for insurers to manage their portfolio in a less concentrated way than they do today, as they do for property, flood and wind coverage which do not benefit from this free federal reinsurance. How companies would react to this increase in the cost of terrorism coverage is a question that future research needs to address and better quantify before moving forward on a public policy front. Our findings also raise the question as to whether insurers themselves even realize they might be overexposed to terrorism risk. Another large-scale attack might be another sad wake-up call to the industry, as 9/11 was ten years ago. 


\section{Acknowledgements}

We very much appreciate Marsh's willingness to share their database with us for research purposes. We would like to thank the editors and two anonymous referees for constructive comments on a previous version of this paper. We also benefited from insightful discussions in the past few years on these issues with Jeffrey Brown, Tilman Bruck, Neil Doherty, Martin Feldstein, Scott Harrington, Dwight Jaffee, Howard Kunreuther, Andre Laboul, David Snyder, Burkhard Pedell, Todd Sandler, Jesse Shapiro, Kent Smetters, Cecile Vignial, Richard Zeckhauser, and the heads of several terrorism insurance programs, including Steve Atkins (Pool Re), Christiane de Bondy (GAREAT), Jeff Bragg (TRIA), Marc Dierckx (TRIP), Bruno Gas and Dirk Harbrucker (Extremus), Michael Holm (Finanstilsynet), Ignacio Machetti (Consortio), Francois Vilnet (GAREAT), and Neil Weeks (Australian pool). We also thank David Rotenberg from the Israeli tax authority for providing us with a better appreciation of how losses from terrorist attacks are compensated in Israel. Participants in the NBER Insurance Group and NBER Economics of National Security workshops, and the OECD conference "Terrorism Insurance in 2010: Where Do We Stand?", organized by the OECD Secretary-General Advisory Board on Financial Management of Catastrophes in Paris, France on June 1 and 2, 2010 also provided valuable feedback. Carol Heller provided excellent research assistance. Partial financial support by the Wharton Risk Management and Decision Processes Center and the AXA and EDF chairs at the Ecole Polytechnique (France) is acknowledged. Usual disclaimers apply.

\section{References}

Abadie, A., Dermisi, S., 2008. Is terrorism eroding agglomeration economies in central business districts? Lessons from the office real estate market in downtown Chicago. Journal of Urban Economics 64, 451-463.

Abadie, A., Gardeazabal, J., 2003. The economic costs of conflict: a case study of the Basque Country. American Economic Review 93, 113-132.

Berrebi, C., Klor, E.F., 2010. The impact of terrorism on the defence industry. Economica 77, 518-543.

Blomberg, S.B., Hess, G.D., Weerapana, A., 2004. Economic conditions and terrorism. European Journal of Political Economy 20, 463-478.

Brück, T. (Ed.), 2007. The Economic Analysis of Terrorism. Routledge, London.

Brown, J., Cummins, D., Lewis, C., Wei, R., 2004. An empirical analysis of the economic impact of federal terrorism reinsurance. Journal of Monetary Economics 51, 861-898.

Cabantous, L., Hilton, D., Kunreuther, $\mathbf{H}$ and E. Michel-Kerjan., Forthcoming. Is imprecise knowledge better than conflicting expertise? Evidence from insurers' decisions in the United States. Journal of Risk and Uncertainty.

Cummins, J.D., Doherty, N., Lo, A., 2002. Can insurers pay for the 'big one? Measuring the capacity of the insurance market to respond to catastrophic losses. Journal of Banking and Finance 26, 557-83.

Drakos, K., Kutan, A.M., 2003. Regional effects of terrorism in three Mediterranean countries. Journal of Conflict Resolution 47, 621-641.

Doherty, N., Lamm-Tennant, J., Starks, L., 2003. Insuring September 11th: market recovery and transparency. Journal of Risk and Uncertainty 26, 179-99.

Enders, W., Sachsida, A., Sandler, T., 2006. The impact of transnational terrorism on U.S. foreign direct investment. Political Research Quarterly 59, 517-531. 
Enders, W., Sandler, T., 2006. The Political Economy of Terrorism. Cambridge University Press, New York, NY.

Frey, B.S., Luechinger, S., 2004. Decentralization as a disincentive for terror. European Journal of Political Economy 20, 509-515.

Frey, B.S., Luechinger, S., Stutzer, A., 2009. The life satisfaction approach to valuing public goods: The case of terrorism. Public Choice 138, 317-345.

Hadi, A.S., 1992. Identifying multiple outliers in multivariate data. Journal of the Royal Statistical Society, Series B, 54, 761-771.

Hale, D., 2002. America uncovered. Financial Times. September 12.

Hoffman, B., 1998. Inside Terrorism.: Columbia University Press, New York, NY.

Jaffee, D., 2005. The role of government in the coverage of terrorism risks. In: OECD (2005), Terrorism Risk Insurance in OECD Countries, Paris, France.

Jaffee, D., Russell, T., 2005. Should governments support the private terrorism insurance market? Unpublished paper. WRIEC conference, Salt Lake City.

Kleffner, A.E., Doherty, N.A., 1996. Costly risk bearing and the supply of catastrophic insurance. Journal of Risk and Insurance 63, 657-671.

Krueger, A.B., Maleckova, J., 2003. Education, poverty and terrorism: Is there a causal connection? Journal of Economic Perspectives 17, 119-144.

Kunreuther, H., Hogarth, R., Meszaros, J., 1993. Insurer ambiguity and market failure. Journal of Risk and Uncertainty 7 (1), 71-88.

Kunreuther, H., Michel-Kerjan, E., 2009. At War with the Weather. MIT Press: Cambridge, MA.

Kunreuther, H., Michel-Kerjan, E., 2005. Insurability of (mega)-terrorism. Report for the OECD Task Force on Terrorism Insurance. In: OECD (2005), Terrorism Insurance in OECD Countries. Paris: Organization for Economic Cooperation and Development, July 5.

Kunreuther, H., Michel-Kerjan, E., 2004. Challenges for terrorism risk insurance in the United States. Journal of Economic Perspectives 18 (4), 201-214.

Lapan, H., Sandler, T., 1988. To bargain or not to bargain: That is the question. American Economic Review 78, 16-20.

Lee, D.R., 1988. Free riding and paid riding in the fight against terrorism. American Economic Review 78, 22-26.

Marsh, 2010. Terrorism Insurance 2010.

Marsh, 2005. Marketwatch: Terrorism Insurance 2005.

Michel-Kerjan, E., 2010. Catastrophe economics: The U.S. National Flood Insurance Program. Journal of Economic Perspectives 24, 165-86.

Michel-Kerjan, E., 2003. Terrorisme a grande échelle: partage de risque et politiques publiques. Revue d'Economie Politique 113, 625-648.

Michel-Kerjan, E., Pedell, B., 2006. How does the corporate world cope with mega-terrorism? Puzzling evidence from terrorism insurance markets. Journal of Applied Corporate Finance 18, 61-75.

Michel-Kerjan, E., Pedell, B., 2005. Terrorism coverage in the post-9/11 Era: A comparison of new public-private partnerships in France, Germany and the U.S. Geneva Papers on Risk and Insurance 30, 144-170.

Mirza, D., Verdier, T., 2008. International trade, security and transnational terrorism: Theory and a survey of empirics. Journal of Comparative Economics 36, 179-194.

Moss, D., 2002. When All Else Fails: Government as the Ultimate Risk Manager. Harvard University Press, Cambridge, MA.

Organization for Economic Cooperation and Development (OECD), 2005. Terrorism Insurance in OECD Countries. Paris, France.

Papke, L., Wooldridge, J., 1996. Econometric methods for fractional response variables with an application to 401(K) plan participation rates. Journal of Applied Econometrics 11, 619-632. 
Renz, L., Curraco, E., Marino, L., 2003. 9/11 Relief and Regranting Funds: A Summary Report on Funds Raised and Assistance Provided. Foundation Center, New York, NY.

Sandler, T., Enders, W., 2004. An economic perspective on transnational terrorism. European Journal of Political Economy 20, 301-316.

Schneider, F., Brück, T., Meierrieks, D., 2010. The economics of terrorism and counter-terrorism: A survey (part I and part II. In: Discussion papers of DIW Berlin 1049 and 1050, DIW Berlin, German Institute for Economic Research.

Smetters, K., 2004. Insuring against terrorism: The policy challenge," In: Litan, R. and Herring, R. (Eds.), Brookings-Wharton Papers on Financial Services, pp. 139-182.

Stern, J., 2003. Terror in the Name of God: Why Religious Militants Kill. Harper Collins, New York, NY

Swiss Re, 2002. Terrorism: Dealing with the new spectre. Focus report, Zurich.

Tavares, J., 2004. The open society assesses its enemies: Shocks, disasters and terrorist attacks. Journal of Monetary Economics 51, 1039-1070.

U.S. Congress, 2002. Terrorism Risk Insurance Act of 2002. HR 3210. Washington, DC, November 26.

U.S. Congressional Budget Office, 2005. Federal Terrorism Reinsurance: An Update. Washington, DC. January.

U.S. Department of the Treasury, Board of Governors of the Federal Reserve System, U.S. Securities and Exchange Commission, Commodity Futures Trading Commission, 2006. Terrorism Risk Insurance: Report of the President's Working Group on Financial Markets. Washington, D.C., September.

U.S. Government Accountability Office, 2005. Catastrophe Risks, U.S. and European Approaches to Insure Natural Catastrophe and Terrorism Risks.

U.S. General Accounting Office, 2002. Terrorism insurance: Rising uninsured exposure to attacks heightens potential rconomic vulnerabilities. Testimony of Richard J. Hillman before the Subcommittee on Oversight and Investigations, Committee on Financial Services, House of Representatives, February 27.

\section{Endnotes}

\footnotetext{
i For instance, Martin Feldstein established a dedicated research group on Economics of National Security at the U.S. National Bureau of Economic Research in 2006.

ii See Schneider, Brück and Meierrieks (2010) for a recent and detailed literature review.

iii In addition to reimbursements provided by insurers, the Federal Victim Compensation Fund was established by the U.S. Congress in the aftermath of 9/11 and provided nearly $\$ 7$ billion in payments to 9/11 civilian and first responder victims' families (CBO, 2005). Private philanthropy played a critical role, too; charitable donations reached an unprecedented $\$ 3$ billion for victims of the attacks (Renz et al., 2003).

iv As we write this article there is still uncertainty about the insured losses from the Japanese earthquake/tsunami of March 2011.

$\checkmark$ Terrorism presents additional challenges for insurers. The likelihood and consequences of a terrorist attack are determined by a mix of strategies and counterstrategies developed by a range of stakeholders and changing over time. This leads to dynamic uncertainty (Michel-Kerjan, 2003). Second, there is an asymmetry of information between government and insurers on the evolving nature of the threat, which stems from government intelligence services being a priori having information about the threat that they do not communicate to insurers for obvious reasons of national security. This presents special challenges for insurers who need information in order to establish predictability (for at least one year, but preferably over a period of years) to price their coverage. - Finally, the level of terrorism risk is partly under the government's control (through government actions to reduce the threat and through foreign policy). Hence, terrorism is a mixed private-public good (Kunreuther and Michel-Kerjan, 2004).

vi Commercial enterprises pay 0.21 euros per thousand of property coverage and another 0.25 euros for business interruption to benefit from this state insurance against extraordinary risks.

vii Other European countries have launched terrorism insurance programs more recently. This is the case of the TRIP (Terrorism Reinsurance and Insurance Pool) in Belgium in 2008 and of the terrorism insurance scheme in Denmark in 2010. Austria established a private terror insurance pool in 2005 without any government support.
} 
viii This number represents victims of the attacks in New York City, Washington, DC, and aboard flight 93 which crashed in Stony Creek Township, Pennsylvania, as well as among teams of those providing emergency service.

ix The complete version of the original Act can be downloaded at: http://www.treas.gov/offices/domesticfinance/financial-institution/terrorism-insurance/claims_process/program.shtml

${ }^{x}$ Many U.S. federal programs established in the past have actually benefited from quasi-systematic renewal since they were first established; that is true of the Price Anderson Act first passed in 1957 to partially indemnify the nuclear industry against liability claims arising from nuclear incidents, of the National Flood Insurance Program established in 1968 for covering flood, and of the California Earthquake Authority created in 1996 to provide insurance against earthquakes in that state. This is true in many other countries as well.

${ }^{x i}$ Workers' compensation coverage is mandatory for a large majority of employers in all states other than Texas, where it is optional. Employers must either purchase insurance or qualify to self-insure. Workers' compensation laws do not permit employers or insurers to exclude coverage for worker injuries caused by terrorism.

xii It was 90 percent before 2007.

xiii The law indicates that some of this federal payment could be recouped over time against all commercial policyholders in the country; a sort of ex post national solidarity. It is not clear, however, if this would even be the case given the political pressure that will certainly arise in the aftermath of another large-scale attack.

xiv As of today, most countries have not developed any insurance market for terrorism, either because they do not consider themselves a target or because the government is de facto the insurer of last resort providing compensation to all the victims (as is the case in Israel, for instance). So this crowding out argument has more relevance for countries like Australia, Belgium, Denmark, France, Germany, Netherland, Spain, the U.K. and the U.S. where the government serves the primary insurers as the reinsurer of last resort.

${ }^{x v}$ The median premium rate for terrorism insurance was down from $\$ 57$ per million (0.0057 percent) in 2004, $\$ 42$ per million (0.0042 percent) to $\$ 37$ per million (0.0037 percent) in 2008 , then to $\$ 25$ per million (0.0025 percent) in 2009 (Marsh, 2005, 2010).

xvi Note that for homeowners' insurance, the federal government provides flood insurance to over 5.3 million families through the 1968-established national Flood Insurance Program (NFIP) (Michel-Kerjan, 2010). State governments are also involved in residential wind coverage through their participation in several residential wind pools (Kunreuther and Michel-Kerjan, 2009). Here our analysis focuses on commercial lines, which are different.

xvii We further performed a number of additional robustness checks; exclusion of clients by industry, size and type, exclusion of influential observations based on Hadi (1992) as well as exclusion of large insurers. Our results pass all these robustness checks. The tables are available upon request from the authors. 